\title{
無電解 Ni-Pめっき材の腐食疲労強度
}

\author{
砂田 久吉*，泉 久司*，長谷川勝彦* \\ Corrosion Fatigue Strength of Electroless Ni-P Plated Steel
}

Hisakichi SUNADA*, Hisashi IZUMI*, Katsuhiko HASEGAWA*

\begin{abstract}
Corrosion fatigue strength of electroless $\mathrm{Ni}-\mathrm{P}$ steel was investigated by rotating bending fatigue test at 0.6 and $60 \mathrm{~Hz}$ in dropping $3 \% \mathrm{NaCl}$ solution. The changes of microstructure of $\mathrm{Ni}-\mathrm{P}$ film by cyclic stressing were examined by $\mathrm{X}$-ray technique. 1. Ni-P film keeps amorphous structure and exhibits an excellent corrosion resistance regardless of the presence of applied stress. 2. Since a pre-microcrystalline forms in $\mathrm{Ni}-\mathrm{P}$ film by cyclic stressing, the corrosion resistance decreases, accompanied by negative shift of the corrosion potential. 3. The corrosion resistance of the plated layer decreases with increasing the number of cyclic stressings or local crystallization. Then corrosion pits were produced on the surface, stress concentration is induced at the bottom of pit and then the pit grows up to corrosion fatigue crack. 4. The corrosion fatigue life of steel was improved by about 50 percent by Ni-P plating, which is not as much as was expected for the amorphous metal.
\end{abstract}

\section{1. 緒 言}

筆者らは,さきに無電解 $\mathrm{Ni}-\mathrm{P}$ めっき表面処理を施し た炭素鋼の回転曲げ疲労試験を実施し, めっき前の素材 にくらべて，その疲労強度がかなり向上すること ${ }^{1)}$ あ るいはめっき膜中の $\mathrm{P}$ 含有量はめっき浴 $\mathrm{pH}$ 值の低下と ともに増加し，機械的諸性質の変化することなど2)を報 告してきた。すなわち $\mathrm{pH}<5$ のめっき浴で得られるめ っき膜の $\mathrm{P}$ 含有量は $7 \mathrm{mass} \%$ を越光，その結晶構造は 液体急冷法によって作製された非晶質材料と全く同じ非 晶質構造を有していることを透過電子顕微鏡観察 ${ }^{32}$ 扰よ び 2 体分布関数 ${ }^{4}$ を用いて明らかにしてきた。 Ni-P 合 金が非晶質構造を示すことは以前から知られていたが， その結晶化過程に関する報告は比較的数少ない。 $\mathrm{Ni}-\mathrm{P}$ 合金は化学還元法だけでなく電析法によっても作 製で き, 加熱処理による結晶化過程に関する考察には増井ら の報告5)がある。また筆者らは非晶質めっき膜の結晶化 は加熱処理のほか, 室温下の繰返し応力によっても局部 的な結晶化が誘起され，その特性を変化させることを報 告してきた。

一方，ある非晶質合金は耐食性にも非常にすぐれてい ることが明らかにされているので，本報告では前報1),2) と同様，炭素鋼に無電解 $\mathrm{Ni}-\mathrm{P}$ めっさを施した試料の人 工海水らん囲気中に括ける回転曲げ腐食疲学強度試験を 行なったので, その結果について報告する。

* 姬路工業大学 (兵672-22 姫路市書写2167)

Himeji Institute of Technology (Shosha 2167, Himeji-shi 671-22)

\section{2. 試料および試験方法}

本実験に用いた炭素鋼は S20C (0.19\% C, 0.36\% Si, $0.50 \% \mathrm{Mn}, 0.008 \% \mathrm{P}, 0.022 \% \mathrm{~S})$ 相当鋼で, これを 1103Kにて焼なまし後, 図 1 に示す寸法に旋削後, 加工 層の影響を除去するため, 電解研摩したものをめっきの 下地材として使用した。

無電解 Ni-P めっき浴組成は表 1 に示す次亜リン酸ナ トリウムを還元剤にしためっき浴で，そのめっき条件は 浴温 $363 \mathrm{~K}, \mathrm{pH} 4.5$, めっき厚さ約 $20 \mu \mathrm{m}$ とし，これをめ っき材とした。

腐食疲労試験には腐食槽を特設した小野式回転曲げ疲 労試験機を用い，繰返し速度0.6および $60 \mathrm{~Hz}$ にて行な った。腐食液は $3 \% \mathrm{NaCl}$ 水溶液を試験片平行部に滴下

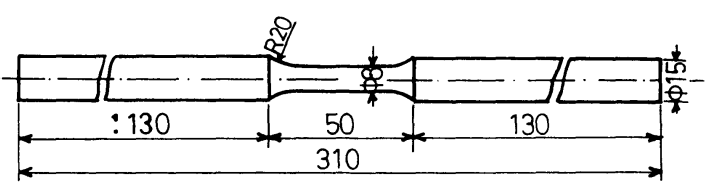

Fig. 1 Size and shape of used fatigue specimen.

Table 1 Bath composition and plating conditions.

\begin{tabular}{cl}
\hline $\mathrm{NiSO}_{4} \cdot 6 \mathrm{H}_{2} \mathrm{O}$ & $30 \mathrm{~g} / 1$ \\
$\mathrm{NaH}_{2} \mathrm{PO}_{2} \cdot \mathrm{H}_{2} \mathrm{O}$ & $109 / 1$ \\
$\mathrm{NaC}_{2} \mathrm{H}_{3} \mathrm{O}_{2} \cdot 3 \mathrm{H}_{2} \mathrm{O}$ & $109 / 1$ \\
$\mathrm{pH}$ & 4.5 \\
Temp. & $363 \mathrm{~K}$ \\
\hline \hline
\end{tabular}


（滴下量0. $3 l / \mathrm{hr}$ ）しながら, 腐食疲労試験を実施した。 腐食分極曲線はポテンシオスタットを用い，めっき膜 表面の $10 \mathrm{~mm} \times 10 \mathrm{~mm}$ を残してフロンマスクで覆って腐 食液に浸し, 参照電極には飽和カロメル電極を使用し た。

めっき膜の繰返し応力による結晶構造変化を調べるた め, まず $\mathrm{Cu}$ 板片面にめっきしたのち下地の $\mathrm{Cu}$ 板のみ を溶解除去してめっき膜を得た。このめっき膜を別に用 意した回転曲げ疲労試験片の表面に接着し, 所定の繰返

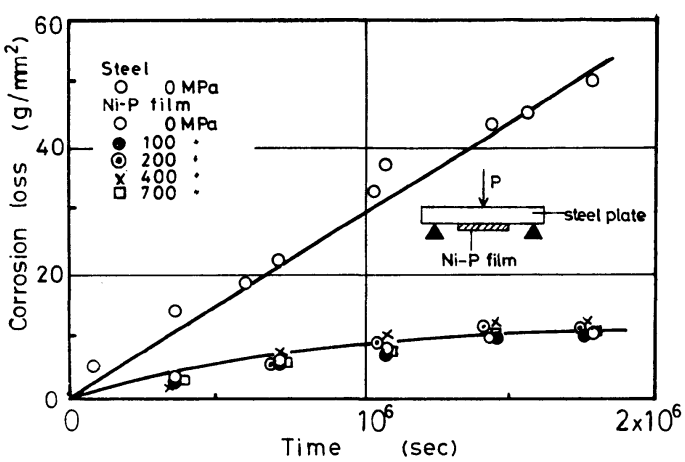

Fig. 2 Weight loss vs immersion time.

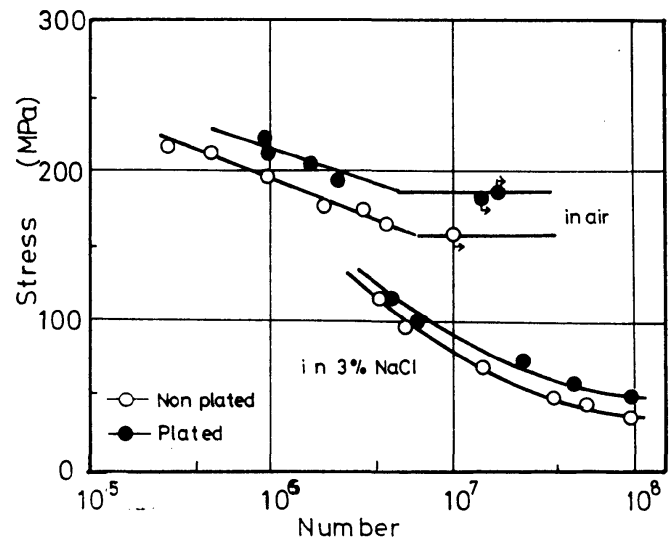

Fig. 3 S-N curves at $60 \mathrm{~Hz}$.

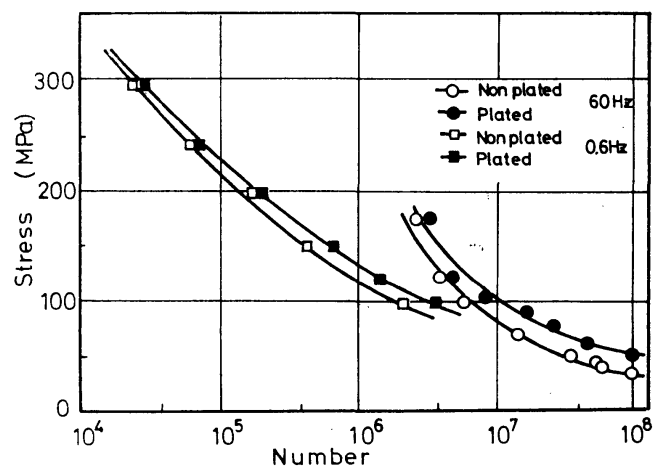

Fig. 4 (a) $\mathrm{S}-\mathrm{N}$ curves in corrosive atomosphere.
し応力を加えた後溶昘にてめっき膜をはく離し， $\mathrm{X}$ 線回 折用試料とした。 $\mathrm{X}$ 線には MoK $\alpha(40 \mathrm{kV}, 15 \mathrm{~mA})$ 線を用 い, 測定範囲 $\mathrm{K}(=4 \pi \sin \theta / \lambda)$ は $6 \sim 100 \mathrm{~nm}^{-1}$ とし, $\Delta \mathrm{K}=0.2 \mathrm{~nm}^{-1}$ 間隔のポイント・カウンティング法によ って前報》と同様にして 2 体分布関数を求めた。

\section{3. 試験結果およびその考察}

腐食疲労試験に先立って応力と腐食環境の共存するふ 几囲気での耐食性を知る目的で鋼扐よびめっき膜に静的 曲げ応力を負荷したまま $3 \% \mathrm{NaCl}$ 水溶液中に浸せさし, その腐食減量を測定した。すなわち，負荷は 3 点曲げ法 により，試験片の圧縮側は被覆して，伸長側に 0 700 $\mathrm{MPa}$ の引張曲げ応力を加えたまま腐食液に浸せきして, その重量変化を測定した。その測定結果を図 2 に示す。 炭素鋼の腐食減量は無応力状態でも浸せき時間の増加と ともにほぼ直線的に増加している。一方, $\mathrm{Ni}-\mathrm{P}$ めっ 膜の腐食減量は負荷応力の大きさに関係なく浸せき時間 の增加とともに飽和する傾向が見られ，静的な応力条件 下では安定な保護被膜を形成するようである。したがっ てこの Ni-P めっき膜の耐食性は完壁なるのとは言えな いが，負荷状態でも鋼にくらべれば明らかに耐食性は良 好で，腐食疲労寿命もかなりの向上が期待される。

図 3 はS20C 扣よびそのめっき材を繰返し速度 $60 \mathrm{~Hz}$ で 大気中拈よび $3 \% \mathrm{NaCl}$ 水溶液滴下らん囲気で腐食疲労 した場合の繰返し応力一破断までの繰返し数（以下これ を S-N 曲線と呼ぶ) 曲線を示す。罒のように大気中では 鋼裸材およびめっき材ともに一定の疲労限を示し, その 值はめっき材のほうが約18\%高くなっており，めっき表 面処理によって疲労強度は改善されている。

次に腐食ふん囲気では裸材, めっき材ともにそれらの $\mathrm{S}-\mathrm{N}$ 曲線は繰返し数の増加とともにその破断強度は漸次 低下し，一定の疲労限は存在しなくなる。しかしめっき 材の S-N 曲線は鋼裸材のそれよりも右上方側に移行し, めっきによる腐食疲労寿命はかなり延び，低応力側ほど 大きい延命効果が認められる。しかし繰返し応力下での めっき膜は図 2 に示したほどの耐食性は確保できないよ

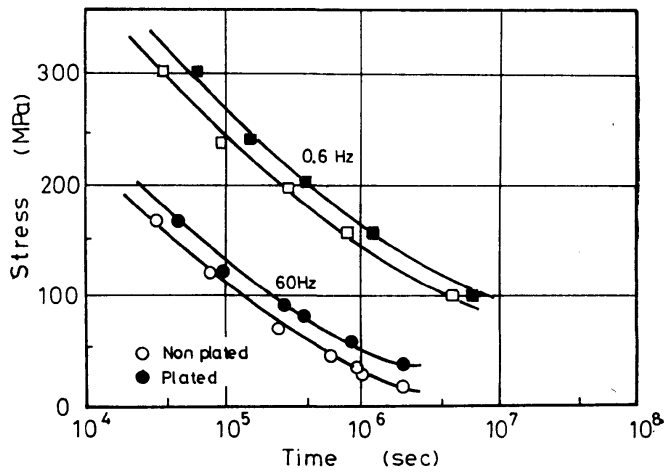

Fig. 4 (b) S-T curves in corrosive atomosphere. 
うである。いずれにせよ，めっき材の腐食疲労強度はめ っき膜自身の耐食性に大きく依存しているょうに思われ る。

図 4 は腐食疲労強度に及ぼす繰返し速度の影響を調べ る目的でその速度を 0.6 扩よび $60 \mathrm{~Hz}$ に変えた場合の S-N 曲線を図 4-(a) に示す。一般に腐食疲労試験では繰 返し速度が遅くなると破断までの絽返し数は減少する が，破断までの試験時間は長くなると言われる。図4-(a)

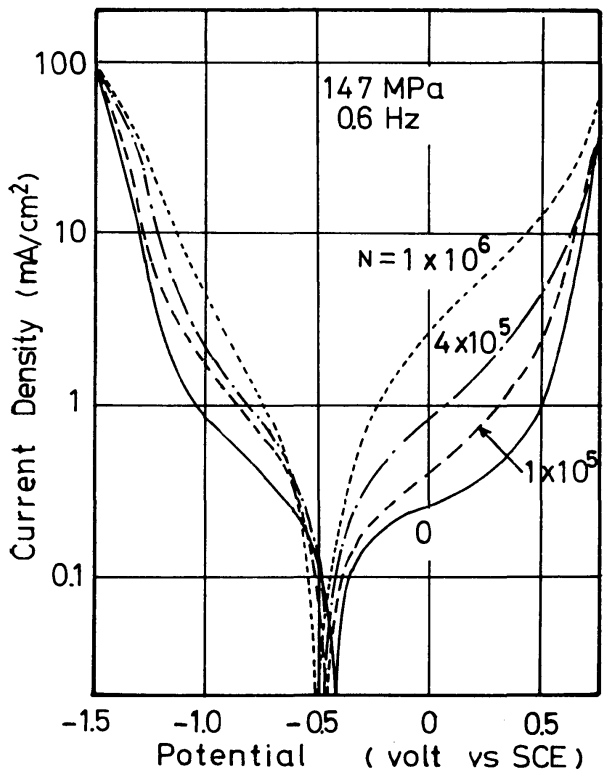

(a) at $147 \mathrm{MPa}$ and $0.6 \mathrm{~Hz}$.

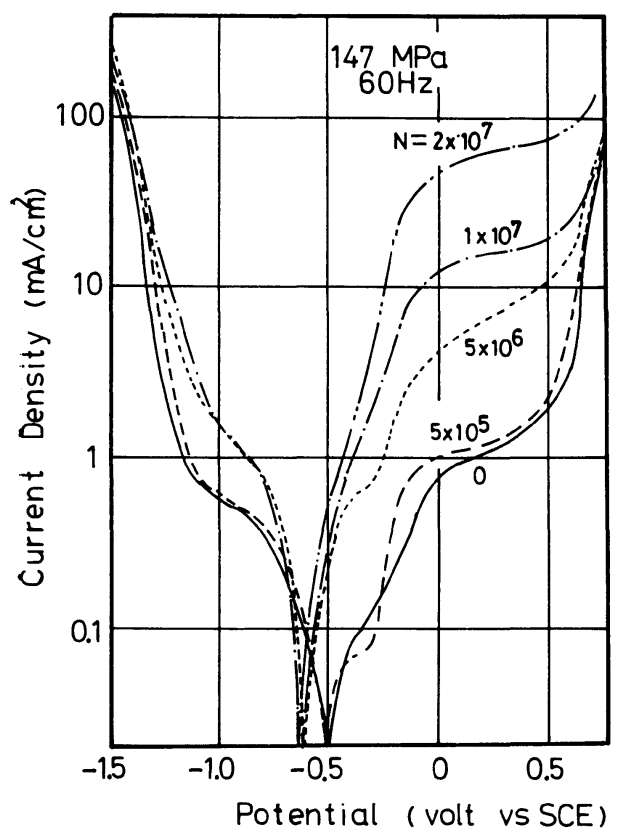

(b) at $147 \mathrm{MPa}$ and $60 \mathrm{~Hz}$.

Fig. 5 Anodic and cathodic polarization curves.
$\mathrm{S}-\mathrm{N}$ 曲線では $60 \mathrm{~Hz}$ 曲線は $0.6 \mathrm{~Hz}$ 曲線の右側にあるが, これを繰返し応力ー破断までの時間曲線（以下これを S-T 曲線と呼ぶ）に再プロットすれば図 4-(b)に示すよ 5 ら $0.6 \mathrm{~Hz}$ 曲線が右上方に移行し，従来の試験結果と同 様な結果となった。

以上の結果より炭素鋼に無電解 $\mathrm{Ni}-\mathrm{P}$ めっきを施すこ とによって腐食疲労寿命はかなり延命される。しかし $\mathrm{Ni}-\mathrm{P}$ めっき膜の防食効果が 図 2 の静的腐食試験結果ほ どに顕著に認められないのは，このめっき膜は動的な繰 返し応力によって腐食電位が低下することや組織的な劣 化挙動を誘発していることが推察される。

図 5 は負荷応力 $\sigma=147 \mathrm{MPa}$ ，繰返し速度0.6および60 $\mathrm{Hz}$ で所定の繰返し数まで腐食疲労させたのちの試験片 の腐食分極曲線の一例を示す。カソード側分極曲線は繰 返し数の増加によって，その電流密度は僅かづつ増加の 方向に移行している。これは腐食疲労中に水素を発生し 易くなり，その腐食速度は加速されているものと考兄ら れる。一方，アノード側では同様に繰返し数の増加とと もに電流密度は增加し，擬似不動態化とみなせるプラト 一部もこわれ，その耐食性の劣化が予想される。さら に, 非晶質構造をるつめっき膜は前報らで述べたごとく， 静的応力条件下では動的応力条件下よりも構造変化を起 こし難い。従って分極曲線の形状に変化を生じた原因は 動的応力によるめっき膜の構造変化と密接な関係を有し ているものと判断した。

また繰返し数の増加とともに腐食電位も早の方向に移 動しているので, めっき膜は疲労の進行に伴い腐食され 易い状態になっているようである。繰返し速度による差 は少ない。これらの分極曲線にターフェル線を引き，腐 食電位 $\mathrm{E}_{\mathrm{c}}$ 就よび腐食電流 $\mathrm{I}_{\mathrm{c}}$ を求め, 繰返し数によるこ れらの值の変化を示した結果が図 6 である。繰返し数の 増加により腐食電位は低下するが，負荷応力による差は 認め難い。しかし同一繰返し速度では高応力のほうが腐

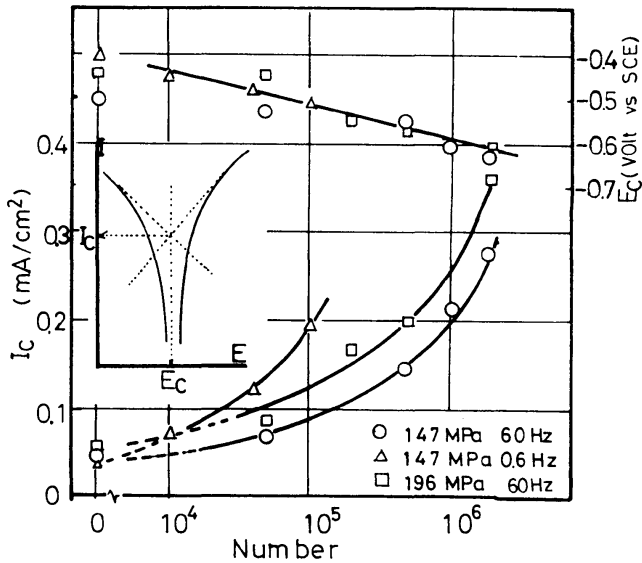

Fig. 6 Effect of the cyclic stressing number on polarization. 
食電流 $I_{\mathrm{c}}$ は大きい。また同一応力では 低繰返し速度の 方が腐食電流が大きくなっているのは腐食時間が長くな り，より腐食が進行していることを示するのと思われ る。

図 7-(a)は繰返し速度 $0.6 \mathrm{~Hz}$, 負荷応力 $\sigma=137 \mathrm{MPa}$, 大気中疲労によるめっき膜の 2 体分布関数 $g(r)$ の変化 を示す。非晶質状態の特徵である ${ }^{6)}$ ，第 1 ピークが鋭く あらわれるとともに第 2 ピークの第 1 サブピーク（約 $\mathbf{r}$ $=0.4 \mathrm{~nm}$ ）の高さが第 2 サブピーク（約 $\mathrm{r}=0.5 \mathrm{~nm}$ ）よ りも高くなるなどの変化が認められる。繰返し数の増加 とともに $\mathrm{r}=0.35 \mathrm{~nm}$ 近くにサブピークの緩和（【印）が

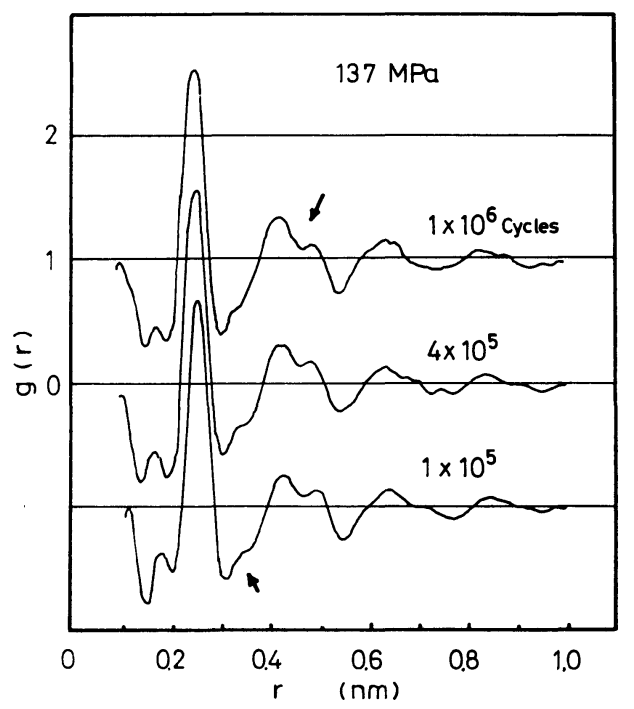

(a) at $137 \mathrm{MPa}$ and $0.6 \mathrm{~Hz}$ in air.

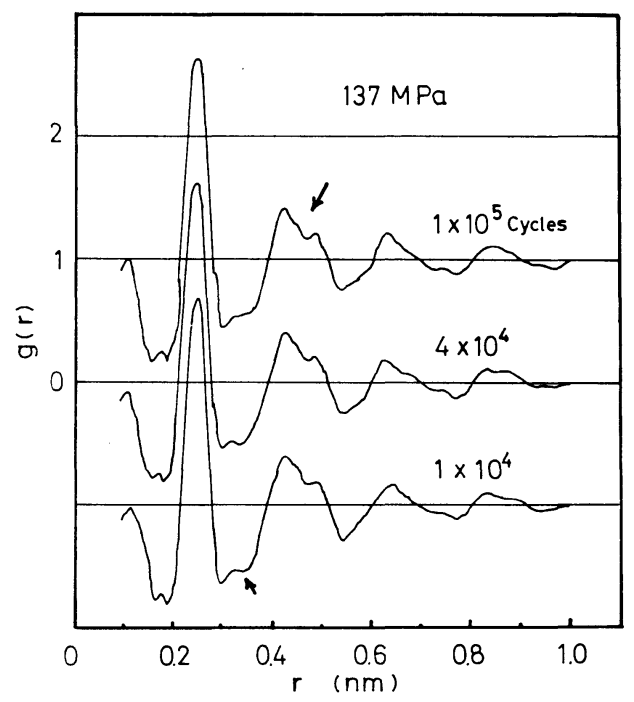

(b) at $137 \mathrm{MPa}$ and $0.6 \mathrm{~Hz}$ under corrosive condition.
みられる。第 2 ピークの分離（ん印）には顕著な変化は みられない。しかし僅かながらの形状変化が認められる ことから，前報》の平面曲げ疲労の場合と同様に何らか の構造緩和，結晶化の前駆段階に達していると考えられ る。すなわち応力による 2 体分布関数曲線の形状变化に 関する報告は数少ないが，压延加工された $\mathrm{Pd}_{80}-\mathrm{Si}_{20}$ 非 晶質合金 ${ }^{7)}$ では第 2 ピークに僅かな緩和がみられてい て, 本実験結果とほぼ同様な傾向が確認されている。

图 7-(b)は試験環境を大気中から $3 \% \mathrm{NaCl}$ 腐食ふ儿囲 気に変えたのみで，他の試験条件は全く同じ場合であ る。繰返し応力による第 2 ピークの変化の状態は大気中 の場合と殆えど同じで，めっき膜の本質的な変化は大気 中の場合と大差のないことがわかる。

図 7-(c)は繰返し速度を $60 \mathrm{~Hz}$ に变化させた場合の 2 体分布関数曲線を示す。四より第 2 ピークに緩和から再 分離の変化を生じているので，低綝返し速度の遅い場合 よりも早く結晶化の前駆段階に達しているようである。

これまでの測定結果から， Ni-P 合金のめっき膜は繰 返し応力によってめっき状態の非平衡相の非晶質状態か ら何らかの局部的な構造緩和を生じているのであろう が， 2 体分布関数からは大気中と腐食環境に上る結晶化 の相違を明確化することは困難である。従ってめっき膜 の耐食性が絽返し応力によって変化する傾向は，むしろ 腐食分極曲線のほらが变化が大きいようである。すなわ ち繰返し応力によって生じた局部的な結晶化域が，特に アノード側で腐食電流によって溶解速度を速めるために 静的応力状態の如き防食効果を発揮しないため，図 2 の $\mathrm{S}-\mathrm{N}$ 曲線に示すように腐食疲労強度の顕著な改善には至 らなかったものと考えられる。

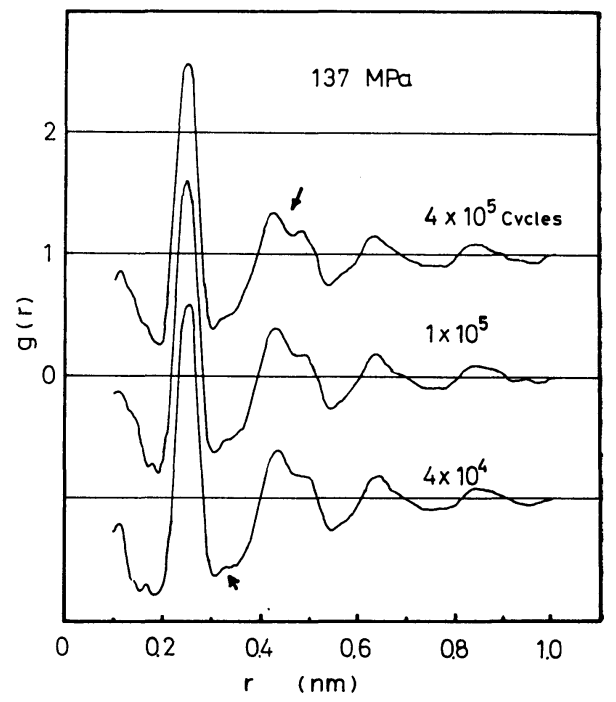

(c) at $137 \mathrm{MPa}$ and $60 \mathrm{~Hz}$ under corrosive condition.

Fig. 7 Changes in the pair distribution function of Ni-P film during cyclic stressing. 
前述したように非晶質構造を示す $\mathrm{Ni}-\mathrm{P}$ 無電解めっき 膜の耐食性は綝返し応力によって若干低下し, 腐食ピッ トを生成し易くなる。图8はとれぞれ腐食疲労被害を受 けためっき朕表面に発生する腐食ピット密度を示す一 例である。(a)㧊よび(b)は $3 \% \mathrm{NaCl}$ ふん囲気で， $\sigma=137$ $\mathrm{MPa}, 60 \mathrm{~Hz}$ の条件下で $\mathrm{N}=10^{5}$ 於よび $10^{6}$ 回腐食労させた ときの腐食ピットであり，(c)怙よび(d)は $0.6 \mathrm{~Hz} て ゙ ~ N=10^{4}$ および $4 \times 10^{4}$ 回腐食疲労させた後の腐食ピットである。 なお比較のため，(e)にはめっき状態のもの（f)は室温で $3 \% \mathrm{NaCl}$ 水溶液中に無応力状態で $2.6 \times 10^{2} \mathrm{ks}(=72 \mathrm{hr})$ 間浸せきしたままのものを示した。いずれにしても腐食 疲労被害を多く受けたるのほどピット密度の高くなって いることが認められる。そこでこれらの腐食ピットを計 量化し，ピット数と応力繰返し数の関係を調べてみた結 果が図9である。四から明らかなように繰返し速度に関 係なく，綝返し数の増加とともにほぼ同じ傾向で腐食ピ ット数も増加している。また同一繰返し数では $0.6 \mathrm{~Hz}$ の 場合は $60 \mathrm{~Hz}$ の場合より腐食ピット数が多く発生してい ることがわかる。この現象もこれまで述べてきたよらに 非晶質めっき膜が多数の繰返し応力によって，局部的な 結晶化前駆段階の過程が発生し, 非晶質域と結晶化域の 間に局部電池が形成され，そこに腐食ピットが誘起され ると同時に，応力集中を起こしやすくなる。したがっ て，そこに腐食疲労き裂が発生し易くなったものと考え ていくと、これまでの実験結果をほぼ都合よく説明でき るるのと考杂ている。

本実験では Ni-P めっき膜の結晶化過程を X線回折よ り推察するに止まり，透過電顕観察などによる確認をす るには至らなかったが，これについては今後検討を加え ていきたい。

\section{4. 結言}

炭素鋼に無電解 Ni-P めっきを施した試料を人工海水 ふん囲気で回転曲げ腐食試験を実施し, 腐食疲労寿命と めっき膜の微細構造の変化について検討した結果を総括 すると次の如くなる。

（1）無電解 Ni-P めっき膜は無応力あるいは静的応力 条件下では非晶質状態を維持し, 負荷応力の大小にかか わらず，かなりすぐれた耐食性を示す。

（2）炭素鋼を無電解 Ni-P めっき膜で被覆することに よって, $3 \% \mathrm{NaCl}$ 水溶液滴下ふん囲気での回転曲げ疲労 強度はかなり向上し, 繰返し速度 $60 \mathrm{~Hz}$ の場合, $\mathrm{N}=10^{8}$ 回疲労強度は裸材に比し，約 $50 \%$ 近く上昇する。

（3）無電解 Ni-P めっき膜は腐食疲学環境中でも繰返 し応力によって，大気中の場合と同様な結晶化前駆段階 挙動を示すことがわかった。このため腐食電位の低下な ど腐食ピットが発生しやすくなり, 耐食性は低下寸る傾 向を示す。

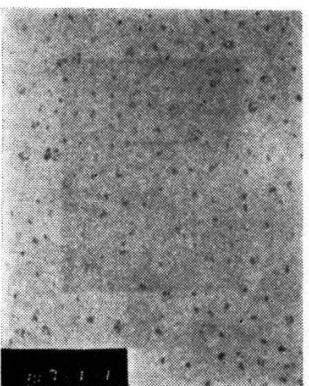

(a) at $137 \mathrm{MPa}, 60 \mathrm{~Hz}$ and $10^{5}$ cycles.

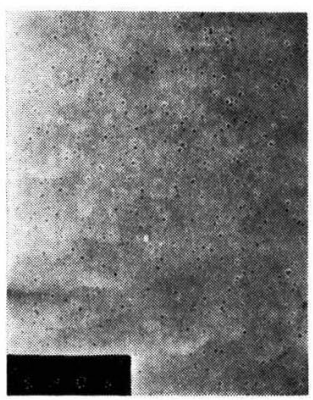

(c) at $137 \mathrm{MPa}, 0.6 \mathrm{~Hz}$ and $10^{4}$ cycles.

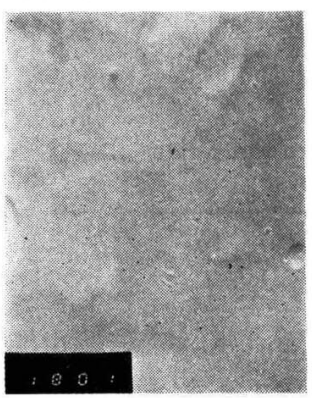

(e) as-plated in air.

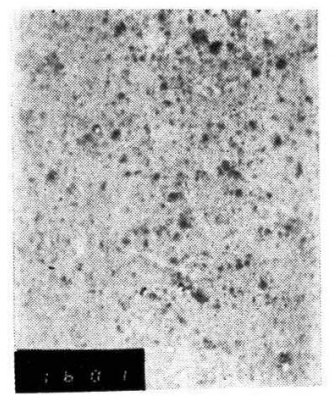

(b) at $137 \mathrm{MPa}, 60 \mathrm{~Hz}$ and $10^{6}$ cycles.

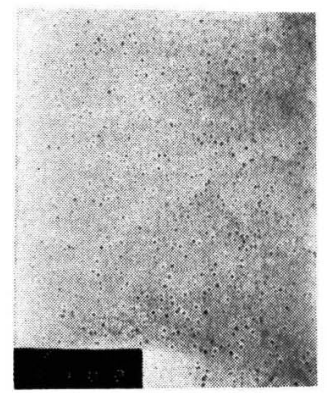

(d) at $137 \mathrm{MPa}, 0.6 \mathrm{~Hz}$ and $4 \times 10^{4}$ cycles.

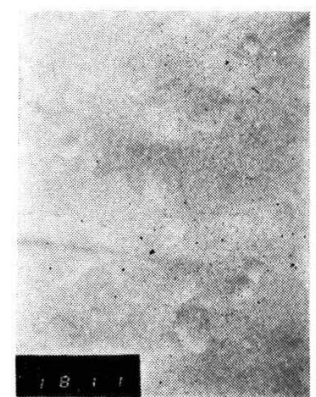

(f) as-plated in $3 \% \mathrm{NaCl}$ for $72 \mathrm{hr}$.

\section{$\stackrel{5 y \mathrm{~m}}{ }$}

Fig. 8 Scanning electron micrographs on the $\mathrm{Ni}-\mathrm{P}$ film.

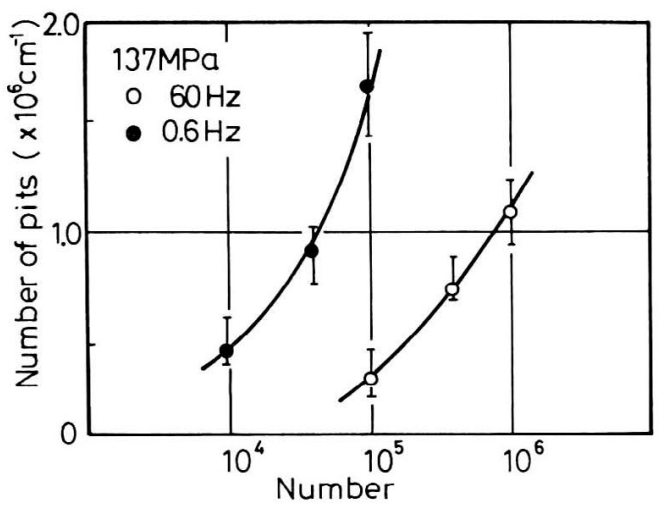

Fig. 9 Relationship between number of pit and that of stress cyclics. 
(4) 無電解 Ni-P めっき膜は腐食環境中の繰返し応力 の綝返し数とともに腐食ピット数も増加し，ここに応力 集中を誘起し，さらに腐食疲労き裂へと成長していく過 程をとる。従って非晶質めっきとして，期待されたほど 顕著な改善には寄与しないことがわかった。

\section{文献}

(1981-8-28 受理)

1）泉 久司, 砂田久吉, 近藤幸夫; 無電解 $\mathrm{Ni}$ めっき 材の疲学強度, 材料, 24, 320 (1975)

2）泉 久司, 砂田久吉, 近藤幸夫; 無電解 $\mathrm{Ni}$ めっき した鋼の疲労強度に拉よぼすめっき膜のリン含有量の 影響, ibid., 26, 164 (1977)

3）泉 久司, 砂田久吉, 近藤幸夫, 山崎徹; 無電解Ni-P
めっき鋼板の疲労強度とめっき層の微細組織, 日本金 属学会誌, 44, 829 (1980)

4) 山崎 徹, 泉 久司, 砂田久吉, 近藤幸夫; 無電解 $\mathrm{Ni}-\mathrm{P}$ ぬっき膜の構造と諸性質におよぼす繰返し応力 の影篭, ibid., 45, 704 (1981)

5 ）増井寬二, 山田敏夫, 久松敬弘; 電析 Ni-P 非晶合 金の結晶化過程，本誌，31，967（1980）

６）早稲田嘉夫；非晶質金属の構造に関する最近のデー タ, 日本金属学会報, 15, 169 (1976)

7) T. Masumoto, Y. Waseda, H. Kimura, and A. Inoue : On Rapidly Quenched Metals, Proc. of 2nd International Conf. (1975) 